https://doi.org/10.37208/tgn27320

\section{Bottlenose whales in the Clyde Sea Area, Scotland in 2020}

\author{
M. O’Reilly ${ }^{1} \&$ A.P. Payne ${ }^{2}$ \\ ${ }^{1}$ Scottish Environment Protection Agency, Angus \\ Smith Building, 6 Parklands Avenue, Eurocentral, \\ Holytown, North Lanarkshire ML1 4WQ \\ ${ }^{2}$ The Thomson Building, Glasgow University, Glasgow \\ G12 8QQ
}

${ }^{1}$ E-mail: myles.oreilly@sepa.org.uk

The northern bottlenose whale (Hyperoodon ampullatus) is the largest of the beaked whales in the European Atlantic, recognised by its size, $7-9 \mathrm{~m}$ in length, bulbous forehead and protruding beak (Fraser, 1976; Evans, 1996). They usually live in pods of four to ten individuals in offshore deep waters (Hooker \& Baird, 1999), feeding mostly on deep-water squid (especially the armhook squid, Gonatus fabricii), but also on a variety of fish and other invertebrates (Martin, 1990; Santos et al., 2001). Bottlenose whales migrate north in spring up to Arctic waters around Iceland, Greenland and Spitzbergen and return south in autumn as far as the Bay of Biscay, occasionally venturing further south to Portugal or the Azores (Van den Brink, 1976; Cresswell \& Walker, 2001).

In north European waters, bottlenose whales occur mainly from March to October (particularly in the months of August and September), with peak sightings in the Bay of Biscay between May and August, off northern Scotland in July-September, and in the Faroes in early March and again in August-September (Evans et al., 2003). In waters adjacent to the U.K. and Ireland, they are primarily found in the Faroe-Shetland Channel, Rockall Trough, and Bay of Biscay, at depths greater than $1,000 \mathrm{~m}$, although they occasionally enter shallower waters (Evans et al., 2003). Those that do stray into shallow coastal waters are at risk of becoming disorientated and malnourished, especially if they wander into estuaries or sea lochs, where they cannot find their usual food (Klinowska, 1985).

In the autumn of 2020 several bottlenose whales entered the Clyde Sea Area, appearing at various locations (Fig. 1), where they were observed, photographed, and videoed by numerous members of the public, and tracked by volunteers from the British Divers Marine Life Recue (BDMLR) organisation. Two whales initially appeared in Victoria Harbour, Greenock, on 22nd August (BBC, 2020a). They left the harbour the next day and were seen heading down the Clyde and up into Loch Long. Over the next couple of days the whales were seen in Loch Goil, with video clips online showing

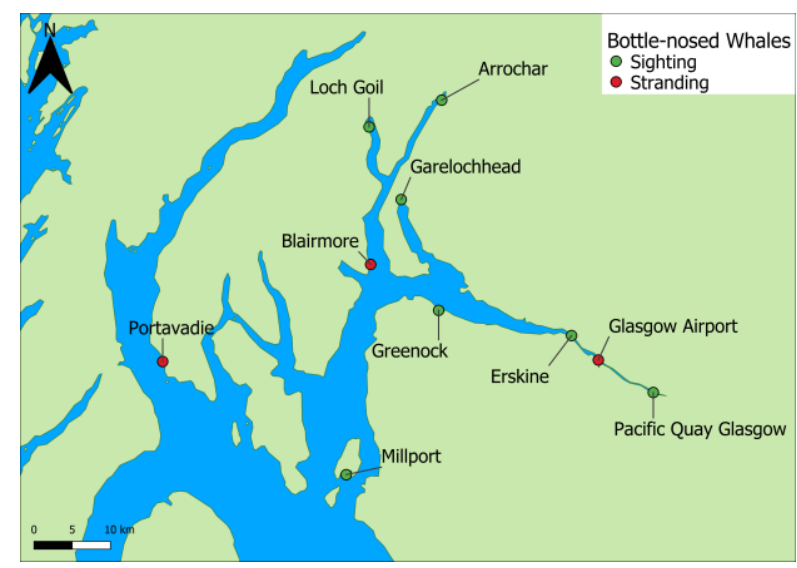

Fig. 1. Sightings and strandings of bottlenose whales (Hyperoodon ampullatus) in the Clyde Sea Area, Scotland in 2020.

them breaching. On 15th September two whales were photographed in Kames Bay, Millport and just a couple of days later three whales appeared in Loch Goil. Between 19th and 22nd September three whales (presumably the same ones) were observed nearby at Arrochar in Loch Long.

On 25th September the three whales arrived in Gare Loch where they stayed until the end of the month. The whales attracted numerous visitors to Garelochhead, where they were observed by MOR on three separate days. The whales patrolled the northern end of the loch and appeared in Garelochhead bay roughly every 20-30 minutes. They manoeuvred around and between the various moored vessels, occasionally approaching close enough to shore so that their breath exhalations were clearly audible. Tail-slapping was frequently seen and occasionally one of the whales would breach producing a spectacular splash. Further crowds of onlookers and photographers gathered on the shores as news of the whales spread on social media. Some people boarded the moored vessels from where they were able to get excellent views of the whales as they cruised by. The police launch from the nearby naval base at Faslane kept watch and prevented smaller craft from disturbing the whales. A TV film crew from the BBC Autumnwatch programme even turned up to film the whales (BBC, 2020b).

Concerns about the welfare of the whales grew and the BDLMR organised an attempt to drive the whales out of Gare Loch on 1st October (BBC, 2020c). This appeared to be unsuccessful (BBC, 2020d), which is perhaps not surprising as bottlenose whales appear to be sensitive to man-made noise and will deep-dive to avoid such disturbance (Miller et al., 2015). However, within a couple of weeks they seem to have left Gare Loch of their own accord. Two whales were spotted in Loch Long at Arrochar on 13th October and remained in this vicinity for several days. One whale was observed here by APP and photographed tail-slapping and breaching (Fig. 2a-c). 

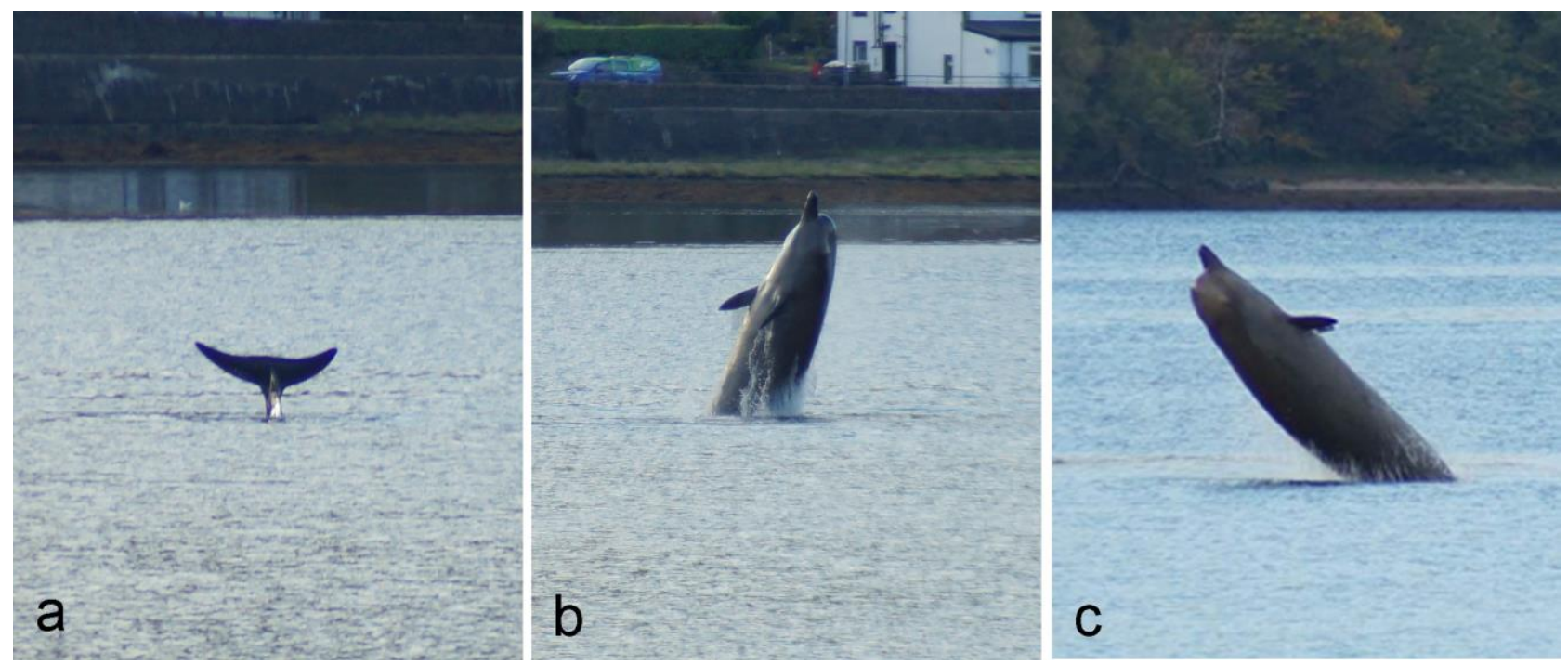

Fig. 2. Bottlenose whales (Hyperoodon ampullatus), Arrochar, Loch Long, Scotland, October 2020. (a) Tail-slapping. (b,c) Breaching. (Photos: A.P. Payne)

On 15th October, a bottlenose whale stranded and died at Blairmore in Loch Long. This whale was identified from markings as one of the two seen in Millport in September. On 18th October, a second whale stranded at Portavadie in Loch Fyne. The next day a single whale was seen swimming at Greenock. On 25th October two whales were spotted in the Clyde Estuary, one near Erskine Bridge and another far upstream near Pacific Quay in Glasgow. The following day a whale stranded and died in the Clyde close to the airport. Necropsies of the stranded whales were carried out by scientists from the Scottish Marine Animal Stranding Scheme (SMASS) and details of their findings will be published in due course on the SMASS website (https://www.strandings.org).

With sightings in different places and at different times it is difficult to be certain exactly how many bottlenose whales were in the Clyde Sea Area in autumn 2020. Because they do not have very distinctive markings or coloration patterns, recognising individuals can be difficult (Gowans \& Whitehead, 2001). BDLMR observations suggest there may have been five or more whales in the area, of which at least three stranded and died. There were also some other sightings in western Scotland around the same time, with one in Loch Creran, Argyll on 12th October, and one stranded near Stornoway (Eilean Leòdhais) on 13th October.

Sightings of live bottlenose whales around the U.K. and Ireland appear to be sparse. The cetacean status review by Evans et al. (2003) shows only about 100 individual whales spotted between 1978 and 2003. Bottlenose whale strandings are also relatively scarce with only 109 records around the U.K. and Ireland between 1800 and 2002 (MacLeod et al., 2004). Although there has been a notable increase in cetacean strandings since the $1980 \mathrm{~s}$, this appears to be due to increased recording effort (Coombs et al., 2019). For bottlenose whales the National Biodiversity Network Atlas for Scotland (NBN, 2020) shows only 16 records, with 13 over the last 20 years. The records include both live sightings and strandings from 11 sites, including Harris, South Uist (both Na h-Eileanan an Iar), Handa Island (Sutherland), Loch Eil, Loch Linnhe (both Argyll), and Wigtown (Dumfries and Galloway) on the west coast and Boyne Bay (Aberdeenshire) and Longannet (Fife) on the east coast. The whale stranded near Longannet in 1988, was found to host some unusual crustacean ectoparasites discussed some years later by O'Reilly (1998). Within the Clyde Sea Area there are just two NBN records for bottlenose whales, a stranding at Port Glasgow in 1896 and a live sighting at Finnieston in September 2009.

However, the NBN records are far from comprehensive. According to Gibson (1976), the bottlenose whale has been a visitor to the Clyde area for around 200 years and is the most frequently seen large cetacean in waters of the Firth of Clyde, with most live animals recorded in late summer or autumn. Furthermore, Gibson lists around 30 bottlenose whale strandings in the Firth of Clyde between 1792 and 1974 with about half of these from within the Clyde Estuary or Gare Loch area. Strandings occurred at Rhu in 1792 and 1941, and within Gare Loch itself in 1863, 1965, and 1974.

Elsewhere in Scotland there are additional old records of bottlenose whales from the Forth cited by McLaren (1981) and more recent records from SMASS Annual Reports, in the Cromarty Firth, 2009 (Brownlow \& Reid, 2010), Skye, 2014 (Brownlow et al., 2015), and Loch Long (Ardentinny), 2017 (Brownlow et al., 2018). The whale washed ashore at Ardentinny in 2017 was visited by MOR (Fig. 3). In 2018 there were 14 strandings of bottlenose whales in northern Scotland, in the Western Isles, Cape Wrath, Orkney, and Shetland. This was part of a highly unusual mass stranding of 118 beaked whales across Scotland, Ireland, Faroes and Iceland (Brownlow et al., 2019; Grove et al., 2020). Lastly, McInerny \& Hoey (2021) reported an observation of two bottlenose whales in the Firth of Forth in August 2020. 


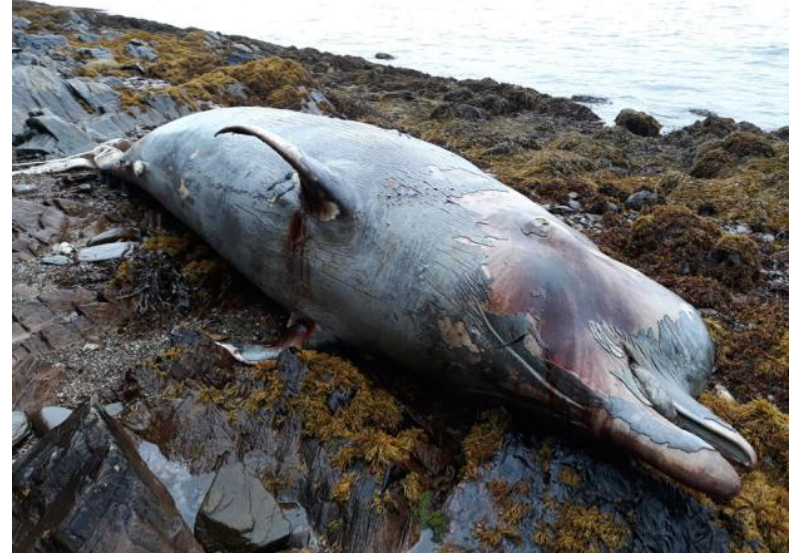

Fig. 3. Bottlenose whale (Hyperoodon ampullatus) carcass, Ardentinny, Loch Long, Scotland, September 2017. (Photo: M. O'Reilly)

While preparing this note we were informed by Janet Mckillop, a Garelochhead resident, about two bottlenose whales that were seen in Gare Loch in October/November 1965 (see above record from Gibson, 1976). She photographed one of the whales, length just under $7 \mathrm{~m}$, after it stranded at Garelochhead (Fig. 4), while the other whale apparently managed to make its way back out of the loch.
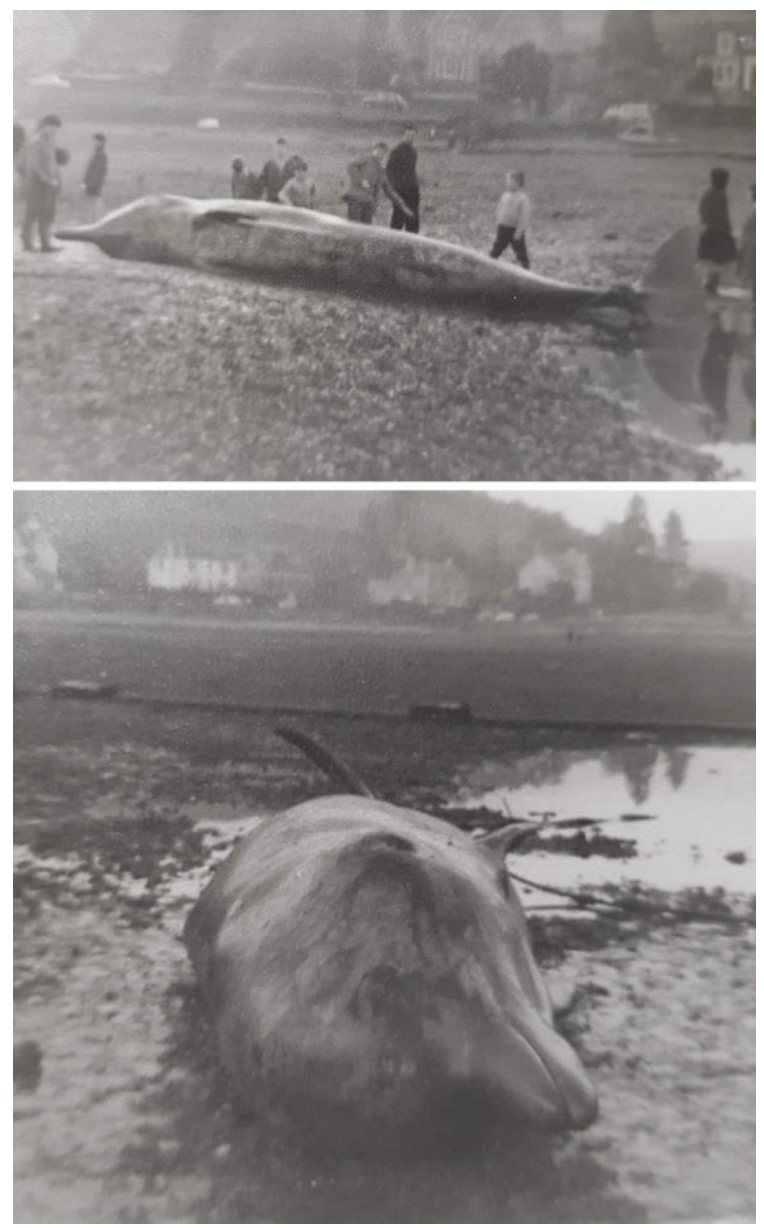

Fig. 4. Bottlenose whale (Hyperoodon ampullatus) stranded at Garelochhead, Gare Loch, Scotland, October/November 1965. (Photos: J. Mckillop)
It is evident that bottlenose whales regularly enter Scottish coastal waters, for largely unknown reasons. While there are some previous cases of them lingering at one location for prolonged periods, such as two at Broadford Bay, Skye which remained for over a month during August/September 1998 (Scott, 1999; Weir, 1999), this is fairly unusual. The pod that entered the Clyde Sea Area in 2020 allowed many people to obtain close views of these enigmatic visitors but the event is tarnished by the fact that, for these deep water whales, shallow coastal waters are often a death trap.

Thanks are due to Elaine O'Reilly, Steve Truluck, David Devoy, and Janet Mckillop who all provided helpful information contributing to this short note. The map in Fig. 1 was prepared by Michelle Elliott. An anonymous reviewer provided very useful suggestions, which improved this Short Note.

\section{REFERENCES}

BBC (2020a). Whales spotted swimming in Greenock Harbour. https://www.bbc.co.uk/news/av/ukscotland-53883178

BBC (2020b). Autumnwatch 2020. Episode 7, broadcast $\mathrm{BBC} 2,5 / 11 / 2020$.

https://www.bbc.co.uk/programmes/m000p3p0

BBC (2020c). Boats herd whales from Gare Loch ahead of military exercise.

https://www.bbc.co.uk/news/uk-scotland-glasgowwest-54355189

BBC (2020d). Rescuers' efforts to herd whales from Gare Loch 'unsuccessful'.

https://www.bbc.co.uk/news/uk-scotland-glasgowwest-54385843

Brownlow, A., Davison, N. \& ten Doeschate, M. (2015). Scottish Marine Animal Stranding Scheme. Annual Report 2014, 1 January to 31 December 2014, for Marine Scotland, Scottish Government. https://www.strandings.org/smass/publications/repo rts/SMASS_Annual_Report_2014.pdf

Brownlow, A., Davison, N. \& ten Doeschate, M. (2018). Scottish Marine Animal Stranding Scheme. Annual Report 2017, 1 January to 31 December 2017, for Marine Scotland, Scottish Government. https://www.strandings.org/smass/publications/repo rts/SMASS_Annual_Report_2017.pdf

Brownlow, A., Davison, N. \& ten Doeschate, M. (2019). Scottish Marine Animal Stranding Scheme. Annual Report 2018, 1 January to 31 December 2018, for Marine Scotland, Scottish Government. https://www.strandings.org/smass/publications/repo rts/SMASS_Annual_Report_2018.pdf https://doi.org/10.31219/osf.io/qkcwg

Brownlow, A. \& Reid, B. (2010). Marine Mammal Stranding Coordination and Investigation (Scotland). Annual Report, 1 January to 31 December 2009, for Marine Scotland, Scottish Government.

https://www.strandings.org/smass/publications/repo rts/SMASS_Annual_Report_2009.pdf

Coombs, E.J., Deauville, R., Sabin, R.C., Allan, L., O'Connell, M., Berrow, S. et al. (2019). What can cetacean stranding records tell us? A study of UK 
and Irish cetacean diversity over the past 100 years. Marine Mammal Science 35, 1527-1555. https://doi.org/10.1111/mms.12610

Cresswell, G. \& Walker, D. (2001). Whales and Dolphins of the European Atlantic, the Bay of Biscay and the English Channel. Ocean Guides, $\mathrm{P} \& \mathrm{O}$, Portsmouth.

Evans, P.G.H. (1996). Guide to the Identification of Whales, Dolphins, and Porpoises in European Seas. Scottish Natural Heritage, Edinburgh.

Evans, P.G.H., Anderwald, P. \& Baines, M.E. (2003). UK Cetacean Status Review. Sea Watch Foundation report to English Nature and Countryside Commission for Wales, Oxford.

Fraser, F.C. (1976). British Whales, Dolphins and Porpoises. A Guide for the Identification and Reporting of Stranded Whales, Dolphins, and Porpoises on the British Coast. (5th edition). British Museum (Natural History), London.

Gibson, J.A. (1976). The marine mammals of the Clyde Faunal Area. Western Naturalist 5, 3-39.

Gowans, S., \& Whitehead, H. (2001). Photographic identification of northern bottlenose whales (Hyperoodon ampullatus): sources of heterogeneity from natural marks. Marine Mammal Science 17, 7693. https://doi.org/10.1111/j.1748-7692.2001.tb00981.x

Grove, T., Senglat, C., Petitguyot, M., Kosiba, D. \& Rasmussen, M.H. (2020). Mass stranding and unusual sightings of northern bottlenose whales (Hyperoodon ampullatus) in Skjálfandi Bay, Iceland. Marine Mammal Science 2020, 1-9. https://doi.org/10.1111/mms.12689

Hooker, S.K. \& Baird, R.W. (1999). Deep-diving behaviour of the northern bottlenose whale, Hyperoodon ampullatus (Cetacea: Ziphiidae). Proceedings of the Royal Society, Series B: Biological Sciences 266, 671-676. https://doi.org/10.1098/rspb.1999.0688

Klinowska, M. (1985). Interpretation of the UK cetacean strandings records. Report of the International Whaling Commission 35, 459-467. Paper no. SC/36/O 9.

MacLeod, C.D., Pierce, G.J., \& Santos Vazquez, M.B. (2004). Geographic and temporal variations in strandings of beaked whales (Ziphiidae) on the coasts of the UK and the Republic of Ireland from 1800-2002. Journal of Cetacean Research and Management 6, 79-86.

Martin, A.R. (1990). The Illustrated Encyclopaedia of Whales and Dolphins. Portland House, New York.

McInerny, C.J. \& Hoey, K. (2021). Unusual aquatic vertebrates in the Firth of Forth, Scotland, during 2020: swordfish and northern bottlenose whales. The Glasgow Naturalist 27(3), 97-98. https://doi.org/10.37208/tgn27308

McLaren, W.B. (1981). Notes on the stranding of a Bottle-nosed Whale on the mudflats at Skinflats. Forth Naturalist and Historian 6, 19-20.

Miller, P.J.O., Kvadsheim, P.H., Lam, F.P.A., Tyack, P.L., Curé, C., DeRuiter, S.L. et al. (2015). First indications that northern bottlenose whales are sensitive to behavioural disturbance from anthropogenic noise. Royal Society Open Science 2, e140484.

https://doi.org/10.1098/rsos.140484

NBN (2020). National Biodiversity Network Atlas Scotland.

https://scotland-species.nbnatlas.org/species/NBNS YS0000005166

Accessed 6th April 2021.

O'Reilly, M. (1998). Whale-lice (Amphipoda: Cyamidae) and sea lice (Copepoda: Caligidae) from stranded whales in the Firth of Forth. The Glasgow Naturalist 23(3), 24-26.

Santos, M.B., Pierce, G.J., Smeenk, C., Addink, M.J., Kinze, C.C., Tougaard, S. \& Herman, J. (2001). Stomach contents of northern bottlenose whales Hyperoodon ampullatus stranded in the North Sea. Journal of the Marine Biological Association of the United Kingdom 81, 143-150. https://doi.org/10.1017/S0025315401003484

Scott, S. (1999). Northern Bottle Nosed Whales off Skye. British Wildlife 10, 89-91.

Van den Brink, F.H. (1967). A Field Guide to the Mammals of Britain and Europe. Collins, London.

Weir, C.R. (1999). Northern bottlenose whales, Isle of Skye. Birding Scotland 2, 12-13. 